\title{
MICROFOSSILS IN A SPECIMEN OF CAMBRIAN (?) SANDSTONE FROM KARSTULA, CENTRAL FINLAND
}

\author{
Risto TynnI \\ Tynni, Risto 1974: Microfossils in a specimen of Cambrian(?) sandstone from \\ Karstula, Central Finland. Bull. Geol. Soc. Finland 46, 9-13.

\begin{abstract}
Fragments of sandstone, believed to be of Cambrian age, occur in the Pleistocene glacial drift at Karstula. The microfossils contained in one pebble were analysed under the microscope and with the aid of scanning electronmicrographs. Four types were defined. They possibly represent blue-green algae and fungi. The tentative dating of the sandstone could not be confirmed, but the results seem to suggest a late Precambrian age.
\end{abstract}

Risto Tynni, Geological Survey of Finland, 02150 Otaniemi, Finland.

\section{Introduction}

In the parish of Karstula, the Pleistocene glacial drift contains fragments of sandstone of unknown provenance. In 1916 Sauramo published the first report on the sandstone. In their survey of Finnish sandstone occurrences, Simonen and Kouvo (1955) gave a petrological description of the Karstula fragments. Its characteristic features are a rich content of quartz (up to 90 per cent of the minerals), and a high degree of sorting. The sandstone is believed to be Cambrian in age.

Sandstone pebbles were found recently at Karstula ( $62^{\circ} 52^{\prime}$ N Lat, $24^{\circ} 42^{\prime}$ E Long) outside the previously known area. The material was collected and submitted to the author by Pro- ferrors H. Stigzelius and K. Virkkala, Geological Survey of Finland. One of the pebbles, $10 \times 12$ $\times 15 \mathrm{~cm}$ in size, was chosen for a study of preserved organic matter. Contamination was avoided by cutting a slab from the interior of the pebble. The organic matter in the slab was enriched by the HF method. The sample obtained was used for a micropalaeontological analysis. Whatever its origin, the matter must have become mixed with the quartz sand prior to diagenesis if not syndepositionally.

The search for microfossils revealed four principal forms, here denoted A (Figs. 1-7), B (Figs. 8-10), C (Figs. 11-12) and D (Figs. 13-15. Of them form $A$ is the most common.

Form A consists of aggregates of vesicles resembling budding yeast cells the smallest less 

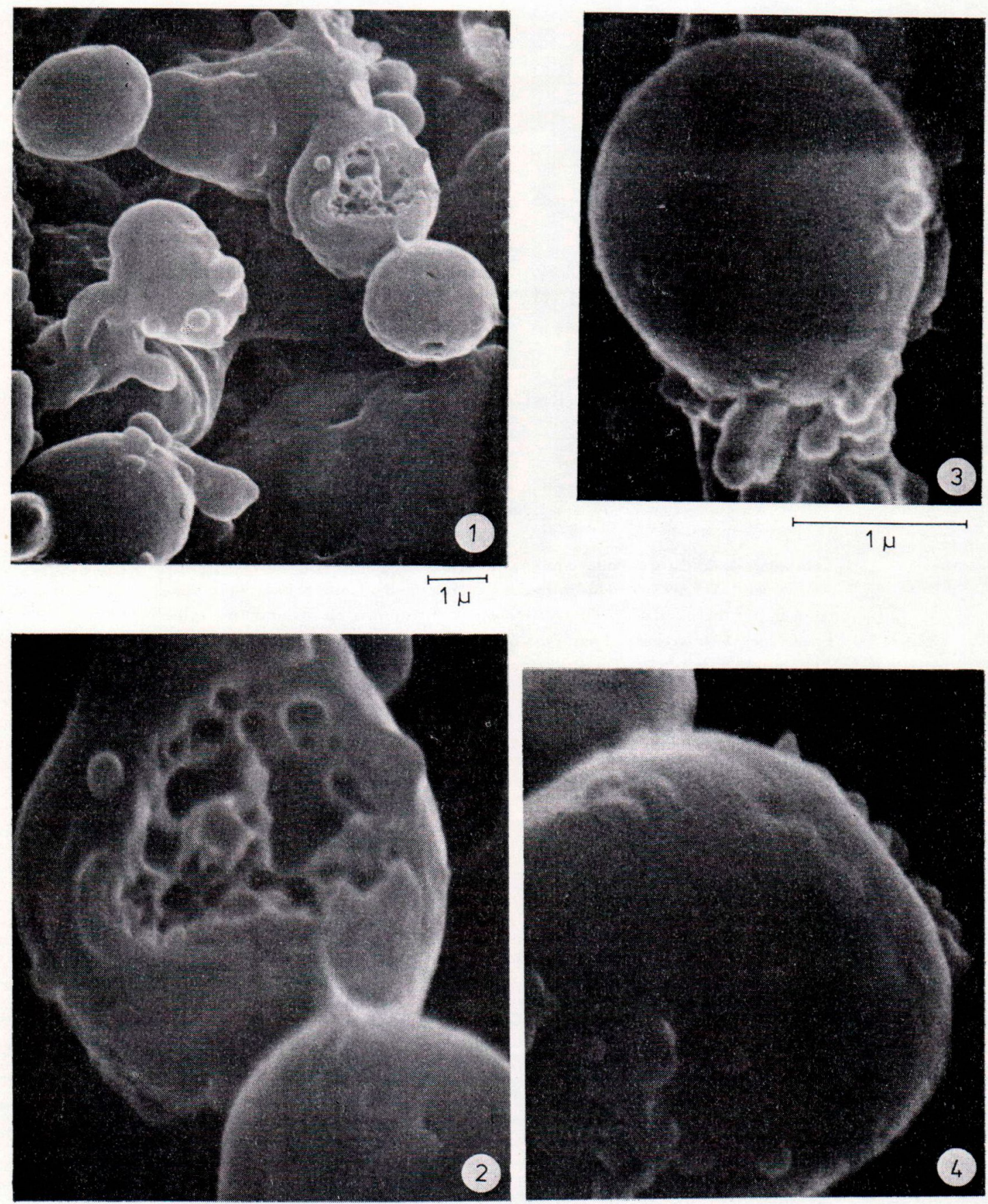

$1 \mu$

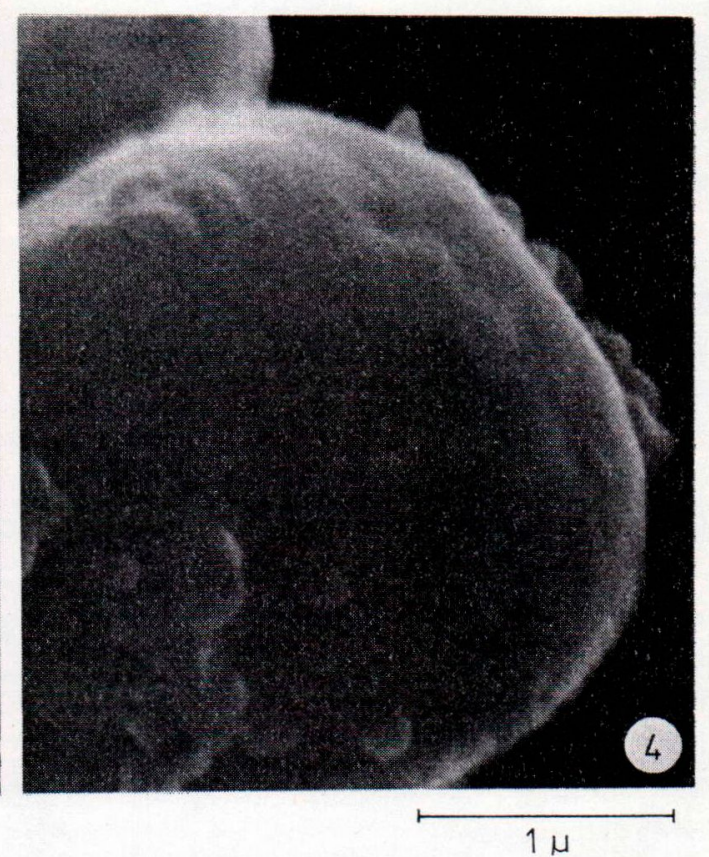

Plate I

Figs. 1-4. Form A: Aggregates of yeast-like budding cells. Scanning electronenmicrographs $\times 10000$ and 30 000. Micrographs by M. Veistaro, Technical University of Helsinki. 
than $0.5 \mu$ in diameter. Scanning electronmicrographs reveal a thin wall and vacuolar interior (Figs. 1-2). The latter might be a secondary feature due to the lithification process.

The form A show features (Fig. 5) that resemble the Synsphaeridium Eisenack identified by Timofeev (1966) and dated as Riphean and Cambrian by him. The budding type (Figs. 15) corresponds morphologically to the Protoleiosphaeridium species described by Combaz (1967) from North African Ludlovian strata. The microfossil presented by Fournier-Vinas (1971, Table XXX: 2) from France is of the same type. According to her, the fossil is probably Precambrian in age. However the Karstula spheroids are distinctly smaller in size. Of the microfossils described by Manum (1967) from the Precambrian Biskopås conglomerate and Biri Shales of Norway, his form B resembles form A of the Karstula Sandstone.

The form B consists of more or less regular spheroids of multicellular aggregates or sporelike bodies with a reticulate structure. The diameter of the colonies or the commonest reticulate spheroids varies from $7 \mu-20 \mu$. The size of the individual cells in the colonies varies between $3 \mu$ and $5 \mu$.

The regular spherical colonies (Fig. 10) resemble Symplassosphaeridium as identified by Timofeev (1966, Plate XXXVII: 3, XLV: 9). His Symplassosphaeridium incrustatum (op. cit., p. 56) occur in the Eocambrian of Finnmarken, northern Norway.

The more irregularly shaped form B colonies of Karstula are very much alike the late Precambrian form C of Manum (1967).

In the Karstula sandstone, the colonies grade into reticulate sphere (Fig. 9). It seems that it corresponds to the Favosphaeridium in Timofeev's classification. Favosphaeridium is known from Riphean beds, but Timofeev (1966, Pl. XVI) has identified it from the Bothnian (Middle Precambrian) schists of the Tampere area in
Finland. The form B sphere resembles the microfossil described from the metasediments of Svecofennian orogeny, Vetlanda series, by Vidal and Röshoff (1971), Fig. $1 \mathrm{E}$ in their paper.

Form B of Karstula also bears a likeness to the stromatolite-associated unicells of Chlorophycean affinities, especially type b, that Cloud and others (1969) have described from East California, although some differences are to be noted, as well.

The objects of form $C$ are larger in size than those of forms A and B. They are spherical in shape, but often torn or irregular (Figs. 11-12). The structures of form $\mathrm{D}$ have the appearance of hyphae (Figs. 13-15). Fig. 13 shows a branched structure typical of some species of Phycomycetes. Hyphae are rare in the Karstula sample but their biogenic origin is the least debatable of the four principal types of structure.

The types of organisms identified from Karstula sandstone have their counterparts in presentday Thallophyta, fungi and algae. These types are known to have existed during the early Palaeozoic, possibly as early as the Precambrian.

The sandstone slab studied does not contain enough phytoplankton or acritarch forms (see Ewitt 1963) to serve for the purpose of certain micropalaeontological dating. Therefore, these microfossils cannot be used to revise or confirm the tentative dating of the Karstula sandstone. However, the resemblance between the late Precambrian microfossils from Norway (Manum 1967) and those from Karstula suggests that Karstula sandstone may be late Precambrian in age. The material presented herein does not lend itself for re-dating the Karstula sandstone as a Jotnian sedimentary rock. A more accurate dating - within the suggested limits — of the Karstula sandstone requires further investigations of its microflora. 

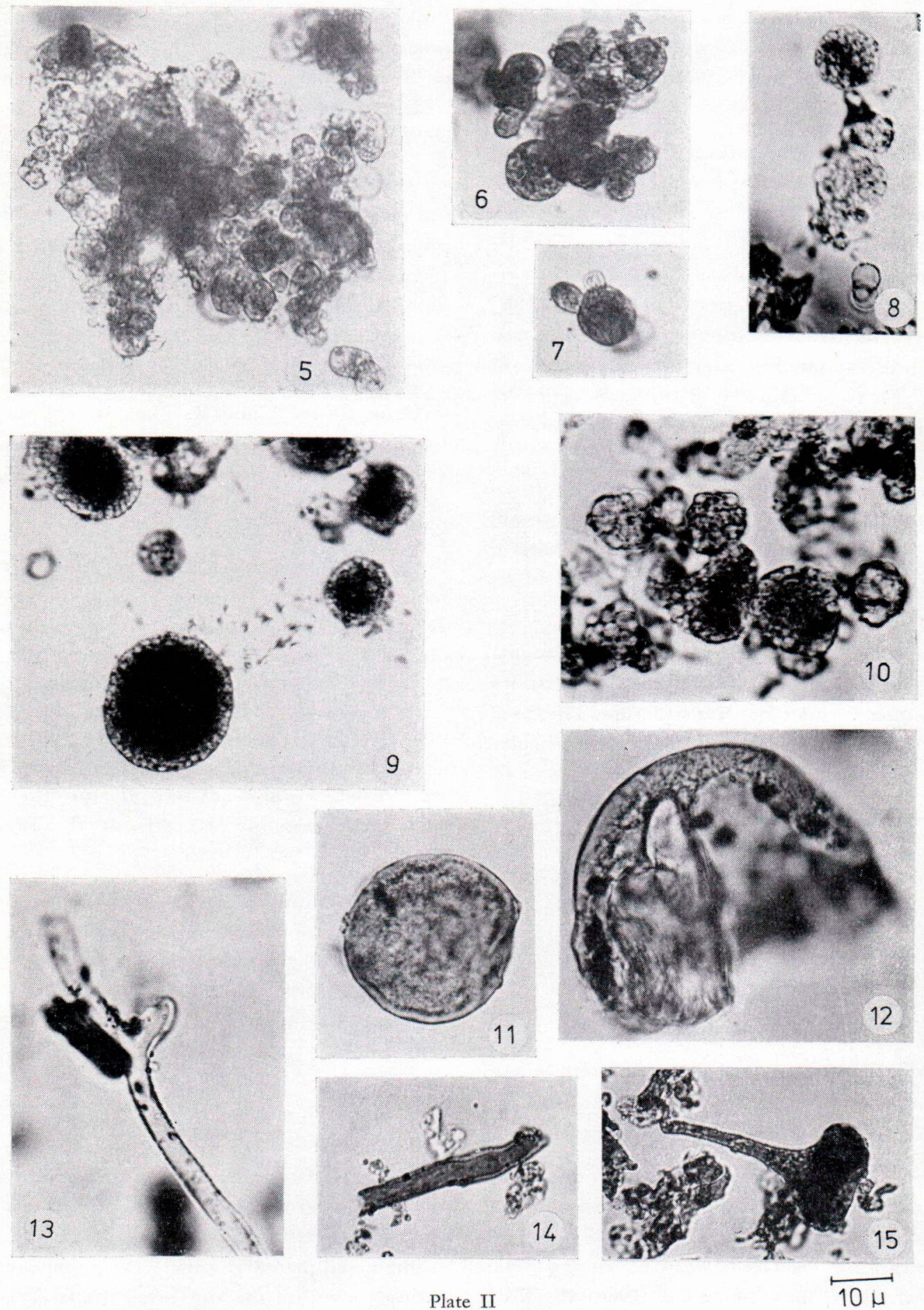

Figs. 5-7. Form A: Cell aggregates as seen under a Leitz Orthoplan microscope; enlargement $\times 1000$. Figs. 8-10. Form B: More or less spherical cell colonies or reticulate spheres.

Figs. $11-12$. Form C: Variable structures, $>20 \mu$ in size. Figs. 13-15. Form D: Tubular filaments. 


\section{REFERENCES}

Cloud, P. E., Jr., G. R. Licari, L. A. Wright, and B. W. Troxel (1969) Proterozoic Eucaryotes from Eastern California. Proc. Nat. Acad. Sci. Vol. 62, Nr. 3, pp. $623-630$.

Сомваz, A. (1967) Leiosphaeridaceae Eisenack, 1954 et Protoleiosphaeridae Timofeev, 1959 - leurs affinités, leur role sedimentologique et géologique. Review of Palaeontology and Palynology 1, 309-321.

Ewitr, W. R. (1963) A discussion and proposals concerning fossil dinoflagellates, hystrichospheres, and acritarchs. Natl. Acad. Sci. U.S. Proc., vol. 49, no. 2, p. 158-164; ibid., no. 3, p. 298-302.

Fournier-Vinas, C. (1971) Recherche de Microorganismes dans le Précambrien métamorphique du Sorézois (Tarn) - Travaux du Laboratoire de Géologie-Pétrologie de l'Université Paul Sabatier. Toulouse.
ManUm, S. (1967) Microfossils from late Precambrian sediments around lake Mjøsa, Southern Norway. Norges Geologiske Undersökelse nr. 251, pp. 45-52. SAURAmo, M. (1916) Über das Vorkommen von Sandstein in Karstula, Finnland. Fennia 39, No. 7, $1-13$.

Simonen, A. and O. Kouvo (1955) Sandstones in Finland. Bull. Comm. géol. Finlande 168, 57-87.

[Trmofeev, В. V.] Тимофеев, Б. В. (1966) Микропалеофитологическое исследование древних свит. "Наука", Москва-Ленинград. 147 р.

VIDAL, G. and K. Röshoff (1971) Organic Remains in Metasedimentary and Metatuffitic Rocks of the Vetlanda Series, South Sweden. A Preliminary Report. GFF, Vol. 93, Part. 4, pp. 773-778.

Manuscript received, May 25, 1973. 